Download

UDC 338.4:612.2:327.3(477)

https://doi.org/10.17721/2308-135X.2019.5

4

$32-40$

Shparaga Tatiana lliodorivna, Candidate of Geographic Sciences, Associate Professor, Taras Shevchenko National University of Kyiv, Kyiv, Ukraine,

e

$-$

mail

:

tatiana.shparaga@gmail.com

" target="_blank">

tatiana.shparaga@gmail.com

Smishchenko Iryna Igorivna, Taras Shevchenko National University of Kyiv, Kyiv, Ukraine, e-m ail

:

irinasmisenko@gmail.com 
The aim of the research. Studying the traditional national dish of Ukrainians - borscht as an intangible cultural heritage of Ukrainian people. Have to be included in the lists of national and world heritage for the purpose of protecting it from being appropriated by other neighboring nations. The reason of substantiation of the necessity of development of the gastronomic brand «

\section{Ukrainian Borsch}

$\gg$

$-$

its promotion in the international and world tourist markets.

Methods. The main research methods are descriptive, comparative, analytical, synthetic, graphic, formalization, scientific systematization.

Results. The history of the dish «Borsch» and the origin of its name are researched. Varieties of borscht and its regional differences within Ukraine have been found out. The classic recipe of the dish, preserved in Central Ukraine, namely in Cherkasy region, is indicated. The differences between Ukrainian borscht and similar first dishes of neighboring nations are shown. The uniqueness of the composition, the technology of preparation and the taste qualities of classic Ukrainian borsch are emphasized. The gastronomic component in the UNESCO World Intangible Heritage has been systematized. The characteristics of national cuisines, gastronomic cultures, diets, specialties and beverages can be found in the World Heritage List. The necessity to include Ukrainian borsch in the national list of intangible cultural heritage and the UNESCO World Intangible Heritage List is substantiated. The algorithm for submitting an element (borsch) to the UNESCO World Intangible Heritage has been ordered. It is shown that Ukrainian borsch meets the requirements for inclusion in the UNESCO list of intangible heritage. A sample account card has been compiled for inclusion in the intangible heritage list. The need to promote borscht through the creation of its culinary brand is outlined. It is suggested to hold a national borsch holiday to preserve and promote the food at the national and international levels.

The scientific novelty of the work is that it is proposed to include borsch, as a traditional first dish of Ukrainians, in the national list of intangible cultural heritage and the list of intangible cultural heritage of UNESCO. It is substantiated that the promotion of the dish internationally requires the development of the Ukrainian Borsch brand.

The practical significance of the research is determined by the protection of borscht from being 
appropriated by other peoples. As well as ability to declare the dish as a gastronomic brand of Ukraine through its listing in the UNESCO World Heritage List.

Keywords: gastronomic culture, national cuisine, traditional dishes, Ukrainian borscht, UNESCO's intangible heritage, element's accounting card, gastronomic brand, national borscht holiday.

\section{References}

1.16 facts about Ukrainian borscht that you didn't know for sure. [Electronic resource] / Access mode: http://vsviti.com.ua/ukraine/51292 (03.02.2020)

2.17 amazing culinary traditions around the world. [Electronic resource] / Access mode: https:// wander-lush.org/food-culture-unesco/ (02.02.2020)

3. The battle for borscht: the way it really is. [Electronic resource] / Access mode: https://www.b bc.com/ukrainian/vert-tra-50074767

$(12.02 .2020)$

4.Borsch Ukrainian. [Electronic resource] / Access mode: https://uateka.com/en/article/culture/ $\underline{991}$ $(05.02 .2020)$

5. Gastronomic brand of St. Petersburg as a way to improve the image of the city. [Electronic resource] / Access mode: (13.02.2020)

6. Gastronomic festivals in Ukraine as a factor in the development of gastronomic tourism. [Electronic resource] / Access mode: http://www.agrosvit.info/pdf/20_2018/4.pdf (13.02.2020) 
7. Electronic petitions. Introduce the 5th official national holiday - borscht. Electronic resource] / Access mode: https://petition.president.gov.ua/petition/77574 (13.02.2020)

8. History of borscht. [Electronic resource] / Access mode: https: //borshchiv.com/borsch-history/ (02.02.2020)

9. Features of Ukrainian borscht cooking. [Electronic resource] / Access mode: https://vseosvita .ua/library/urok-na-temu-personality-prigotuvanna-borsiv-ukrainskoi-kuhni-tehnologia-prigotuva nna-borsu-ukrainskogo-186209.html

$(10.02 .2020)$

10. Theory and practice: borscht. [Electronic resource] / Access mode: https:

//reston.ua/eng/kyiv_topics/teoriya-i-praktika-borsch (05.02.2020)

11.Ukrainian cuisine. [Electronic resource] / Access mode: http://ua-referat.com/\%D0\%A3\%D0 \%BA\%D1\%80\%D0\%B0\%D1\%97\%D0\%BD\%D1\%81\%D1\%8C

$\%$ D0\% BA\% D0\% B0_\% D0\% BD\% D0\% B0\% D1\% 86\% D1\% 96\% D0\% BE\% D0\% BD\% D0\% B0\% D0\% BB\% D1\% 8C\% D0\% BD\% D0 \% B0_\% D0\% BA\% D1\% 83\% D1\% 85\% D0\% BD\% D1\% 8F_2 (03.02.2020)

12.Ukrainian Center for Cultural Research. Intangible cultural heritage of Ukraine. [Electronic resource] / Access mode: anager/2018-08-17 2.pdf http://uccs.org.ua/wp-content/uploads/bsk-pdf-m (02.02.2020)

13. How is Ukrainian cuisine different from Russian. [Electronic resource] / Access mode: https: //h.ua/story/57383/

$(12.02 .2020)$

14. Wonderful borscht. Online resource] / Access mode: https://www.livejournal.com/interesting

$(11.02 .2020)$ 
UNESCO has included Neapolitan pizza in the list of intangible heritage. [Electronic resource] / Access mode: https://gordonua.com/news/worldnews/yunesko-vnesla-neapolitanskuyu-piccu-v -spisok-nematerialnogo-naslediya-220970.html

$(13.02 .2020)$ 